\title{
PENENTUAN PENGARUH KEMAMPUAN HASIL BELAJAR AKUNTANSI BERDASARKAN INTELEKTUAL (IQ) DAN MOTIVASI BELAJAR DENGAN PENDEKATAN FUZZY INFRENCE SYSTEM MAMDANI
}

\author{
Syamsiah \\ Dosen Program Studi Teknik Informatika Universitas Indraprasta PGRI \\ Email: ncham.unindra08@gmail.com
}

\begin{abstract}
Abstrak
Penelitian ini bertujuan untuk mengetahui seberapa besar pengaruh kemampuan intelektual (IQ) dan motivasi belajar terhadap hasil belajar siswa pada mata pelajaran Akuntansi di SMA XYZ. Yang berlokasi di DKI Jarkarta dan dilakukan pada bulan Oktober sampai dengan desember 2015. Penelitian ini dengan metode Fuzzy madani, Populasi adalah seluruh siswa di SMA XYZ, dengan populasi terjangkau siswa kelas XI IPS dengan jumlah 158 siswa, dengan mengambil sampel 110 responden.Instrument yang digunakan dalam bentuk kuesioner, dalam bentuk 35 pernyataan untuk variable bebas Motivasi Belajar dan untuk data Kemampuan Intelektual (IQ) dan Hasil Belajar Akuntansi siswa di dapat langsung dari sekolah. Dalam variabel Motivasi Belajar dari 35 pernyataan yang diajukan terdapat 5 pernyataan yang dinyatakan tidak valid. Hasil dari perhitungan variabel motivasi belajar memiliki reliabilitas sebesar 0,961 . Hasil ini selanjutnya dinyatakan reliabel digunakan untuk mendapatkan data. Dari hasil penelitian dapat digambarkan pengaruh kemampuan intelektual dan Motivasi Belajar terhadap Hasil Belajar Akuntansi menunjukkan hubungan positif yaitu terdapat pengaruh positif antara Kemampuan Intelektual siswa dan Motivasi Belajar Terhadap Hasil Belajar Siswa Pada Mata Pelajaran Akuntansi.
\end{abstract}

Kata kunci: Kemampuan Intelekual ( IQ ), Motivasi Belajar, Hasil Belajar Akuntansi dan Fuzzy Madani

\section{PENDAHULUAN}

Setiap manusia mempunyai berbagai macam kebutuhan yang harus dipenuhi. Dalam ilmu ekonomi kebutuhan setiap individu terbagi atas kebutuhan primer, sekunder dan tersier. Paling pokok dan harus senantiasa terpenuhi adalah kebutuhan primer yang terdiri atas sandang, pangan, papan, kesehatan dan pendidikan.

Pendidikaan digolongkan kedalam kebutuhan primer karena pada dasarnya setiap individu itu perlu untuk belajar, karena dengan seseorang dapat membuka cakrawala dunia dan dapat menjawab rasa keinginantahuan terhadap sesuatu hal yang baru. Secara formal, kegiatan belajar berlangsung di sekolah dan setiap individu atau siswa diberikan materi disesuaikan dengan tingkat usia, lingkungan sosial budaya, serta kebijakan pemerintah. Untuk mengetahui sejauh mana tingkat pemahaman siswa terhadap materi yang diberikan dan mengukur keberhasilan program pembelajaran, maka diadakanlah suatu evaluasi dimana nilai evaluasi inilah yang digambarkan sebagai hasil belajar siswa.

Hasil belajar yang didapat setelah melalui evaluasi dinyatakan dalam bentuk angka, yang mencerminkan potensi siswa tersebut setelah melalui proses pembelajaran. Dalam pendidikan formal disekolah, prestasi dari hasil belajar siswa dianggap sebagai gambaran dari kecerdasan siswa tersebut. Walaupun dalam hal pemberian materi dan frekuensi belajar di sekolah itu sama besar, namun tidak semua siswa mendapatkan hasil sama setelah proses pembelajaran, hal ini dikarenakan adanya beberapa faktor secara khusus yang dapat mempengaruhi hasil 
belajar siswa. Diantaranya adalah kecerdasan siswa yang berbeda-beda dalam suatu kelas, motivasi belajar siswa, frekuensi belajar siswa dirumah, metode pengajaran oleh guru dalam kelas, sarana dan prasarana dalam kegiatan pembelajaran. Faktor yang pertama yaitu kecerdasan (inteligensi).

Kecerdasan atau inteligensi merupakan salah satu faktor yang cukup berpengaruh, karena merupakan kapasitas berpikir seseorang yang kemudian menentukan cara berpikir seorang tersebut. Adanya suatu perbedaan kecepatan dan kesempurnaan seseorang dalam memecahkan masalah berbagai persoalan yang dihadapi, memperkuat pendapat bahwa inteligensi itu memang ada dan berbedabeda pada setiap orang. Intelegensi besar pengaruhnya terhadap kemajuan belajar. Dalam situasi yang sama, siswa yang mempunyai tingkat intelegensi yang tinggi akan lebih berhasil daripada siswa yang mepunyai tingkat intelegensi yang rendah. Walaupun begitu siswa yang mempunyai tingkat intelegensi yang tinggi belum pasti berhasil dalam belajarnya.

Selain dari kecerdasan dalam diri anak, faktor yang lain mempengaruhi hasil belajar adalah motivasi. Motivasi dapat berupa keinginan untuk menjadi juara kelas, keinginan untuk mendapat beasiswa, keinginan untuk membahagiakan orang tua dan lain sebagainya. Jika semua keinginan itu sangat kuat, otomatis akan membangkitkan tenaga yang luar biasa dalam diri untuk dapat mencapai keinginan tersebut. Motivasi belajar merupakan salah satu karakteristik yang dapat mempengaruhi aspek afektif. Motivasi dalam belajar menjadi sangat penting bagi siswa, dengan motivasi yang kuat, ia akan berusaha sekuat tenaga untuk mencapai apa yang dicita-citakan.

Mata pelajaran akuntansi merupakan mata pelajaran yang mencakup berbagai kemampuan dan keterampilan dalam berperilaku dan pemahaman terhadap transaksi keuangan lembaga ekonomi. Keberhasilan proses pembelajaran sangat tergantung pada kemampuan dan apresiasi guru. Guru Akuntansi perlu memahami misi kurikulum, perspektif dan pendekatan masingmasing satuan kompetensi dasar yang harus dicapai. Oleh karenanya, pembelajaran mata pelajaran Akuntansi memberikan keluasan guru untuk mengelola pembelajaran sesuai dengan potensi daerah, kondisi sekolah dan mendorong siswa untuk lebih memanfaatkan sumber- sumber belajar yang ada di sekolah dan lingkungannya. Agar pembelajaran lebih bermakna, maka organisasi penyajian dimulai dari penguasaan pengertian dasar akuntansi sampai pada penerapannya dan penafsirannya terhadap hasil maupun proses.

Penilaian hendaknya tidak hanya dilakukan sesaat, akan tetapi harus dilakukan secara berkala dan berkesinambungan. Di samping itu penilaian bukan hanya menaksir sesuatu secara parsial, melainkan harus menaksir sesuatu secara menyeluruh yang meliputi proses dan hasil pertumbuhan dan perkembangan wawasan pengetahuan, sikap, dan keterampilan yang dicapai siswa. Seperti yang telah dijelaskan sebelumnya, Intelegensi besar pengaruhnya terhadap kemajuan belajar. Dalam situasi yang sama, siswa yang mempunyai tingkat intelegensi yang tinggi akan lebih berhasil daripada siswa yang mepunyai tingkat intelegensi yang rendah. Walaupun begitu siswa yang mempunyai tingkat intelegensi yang tinggi belum pasti berhasil dalam belajarnya. Pembahasan materi dalam mata pelajaran akuntansi harus dilakukan melalui pendekatan pembelajaran secara tuntas, karena mata pelajaran akuntansi merupakan suatu siklus sehingga keterampilanyang satu berkaitan dengan keterampilan yang lainnya dan lebih 
mengutamakan target pencapaian yang dialami langsung siswanya. Oleh karena itu, peneliti bermaksud mencari tahu apakah ada pengaruh inteligensi (IQ) yang dimiliki siswa dalam menerima dan mengikuti mata pelajaran akuntansi dan seberapa besar motivasi belajar siswa terhadap mata pelajaran akuntansi di SMA XYZ .

\section{MASALAH}

\section{Kemampuan Intelektual (IQ)}

Kecakapan anak didik dapat diperhatikan dari cara hidup dan berinteraksi didalam lingkungannya yang kompleks. Untuk itu ia memerlukan kemampuan untuk menyesuaikan diri dengan lingkungan demi kelestarian pertumbuhannya, tetapi juga untuk perkembangan pribadinya. Oleh karena itu, manusia harus belajar dari pengalaman.

Super \& Cites mengemukakan definisi yang sering dipakai sementara oleh banyak orang sebagai berikut: "intelligence has frequently been defined as the ability to adjust to the environment or to learn fromexperience" (inteligensi telah sering didefinisikan sebagai kemampuan menyesuaikan diri dengan lingkungan atau belajar dari pengalaman).

Definisi lain tentang inteligensi dikemukakan oleh Bischof, seorang psikolog Amerika (1954) dengan artian lebih luwes, namun bersifat operasional dan fungsionall bagi kehidupan manusia sehari-hari. Ia mendefinisikan, "intelligence is the ability to solve problems of all kinds" (inteligensi ialah kemampuan untuk memecahkan segala jenis masalah).

Dalam konteks subyek inteligensi khusus pada anak didik di sekolah, maka dengan rumusan definisi yang berbeda namun pengertiannya sama dengan dikemukakan Bischof, Heidenrich (1970) mengemukakan sebagai berikut: "intelligence refers to the ability to learn and utilitize what has been learned in adjusting to unfamiliar situations, or in the solving of problems" (inteligensi menyangkut kemampuan untuk belajar dan menggunakan apa yang telah dipelajari dalam usaha penyesuaian terhadap situasi-situasi yangkurangdikenal, atau dalam pemecahan masalah-masalah).

Manusia yang belajar sering menghadapi situasisituasi baru serta permasalahan dalam pembelajaran yang dialami. Hal itu memerlukan kemampuan individu yang belajar menyesuaikan diri untuk menyesuaikan diri serta memecahkan setiap permasalahan yang dihadapi. Dari ketiga definisi di atas dapat dipahami meskipun rumusnya berbeda-beda, namun mengandung isi dan pengertian yang sama dalam arti tidak bertentangan. Dalam definisi tersebut secara implicit diartikan inteligensi merupakan kemampuan "problem solving" dalam segalasituasi yang baru atau yang mengandung maslaah, khususnya dalam masalah belajar pada siswa sebagai peserta didik.

Walter B. Kolesnik dalam Djamarah mengatakan bahwa "in most cases there is a fairly high correlation between one's IQ, the higher grades he receives 8 (Terdapat korelasi yang tinggi antara IQ dengan prestasi yang ia dapatkan.Dimana IQ memuiliki korelasi terhadap daya tangkap seseorang, sehingga benar yang dikatakan oleh para ahli diatas semakin tinggi IQ anak didik maka akan semakin mudah ia menerima dan mengerti materi pelajaran sehingga akan dipastikan ia mendapatkanprestasi yang baik pula. "Intelligence Quotient atau sering di singkat IQ merupakan suatu nilai yang menggambarkan 
mengenai, seberapakah tingkat kecerdasan seseorang bila dibandingkan orang lain".

Setiap tahun sekolah menengah pertama dan sekolah menengah atas selalu menyaring calon anak didik dengan berbagai kriteria dari nilai hasil ujian dan raport untuk dapat mengetahui apakah anak tersebut memiliki prestasi belajaryang baik dan dapat melanjutkan sekolah dengan terus berprestasi, dimana secara eksplisit setiap sekolah ingin mendapatkan anak-anak yang cerdas dan memiliki kompetensi tinggi. Maka dari itu kebanyakan anak didik yang telah diterima tiap tahun ajaran baru selalu diberikan tes kecerdasan pada semester awal untuk dapat mengetahui bagaimana kecerdasan dan cara mendidik para siswa, maka sebelum penjurusan pada tingkat sekolah menengah atas umumnya dilakukan tes kecerdasan atau inteligensi (tes-IQ), “

Hasil tes inteligensi dinyatakan dalam angka, yang menggambarkan perbandingan antara umur kemampuan mental atau kecerdasan. Dari hasil pengolahan tersebut maka akan diberikan dalam bentuk sebuah laporan pribadi yang bersifat rahasaia yang ditujukan pada masingmasing siswa, maka hasilnya merupakan menunjukkan tentang nilai kecerdasan berupa angka, kecerdasan, serta panduan bakat dan minat yang dapat dijadikan patokan untuk pribadi para siswa dalam mengenal lingkungan dan cara-cara memecahkan masalah yang dihadapinya termasuk dalam belajar dan bersosialisasi.

\section{Konsep Motivasi Belajar}

Motivasi berasal dari kata "motif" yang artinya daya upaya yang mendorong seseorang untuk melakukan sesuatu. Motif dapat dikatakan sebagai daya penggerak dari dalam dan didalam subyek untuk melakukan aktivitas- aktivitas tertentu demi mencapai suatu tujuan. Berawal dari kata "motif", maka motivasi dapat diartikan sebagai daya penggerak yang telah menjadi aktif. Motif menjadi aktif pada saatsaat tertentu bila kebutuhan untuk mencapai tujuan sangat dirasakan atau mendesak, hal tersebut serupa dengan pengertian motif menurut Ngalin Purwanto yang mengutip pendapat pendapat Sartain adalah 'suatu pernyataan yang kompleks di dalam suatu organism yang mengarahkan tingkah laku atau perbuatan ke suatu tujuan atau perangsang" Mengungkap lebih lengkap lagi pemahaman dari Hamzah B.Uno yang mengutip pendapat dari Robert C.Beck, "motivasi berasal dari kata motif yang dapat diartikan sebagai tenaga penggerak yang mempengaruhi kesiapan untuk memulai rangkaian kegiatan dalam suatu perilaku”. Menurut Mc Donald yang dikutip oleh Sardiman, "Motivasi adalah perubaan energi dalam diri (pribadi) seseorang yang ditandai dengan munculnya perasaan dan reaksi untuk mencapai tujuan ". Dimana dalam rumusan tersebut ada tiga unsur yang saling berkaitan, ialah sebagai berikut:

1. Motivasi dimulai dari adanya perubahan energi dalam pribadi misalnya karena terjadi perubahan organisme manusia dalam pencernaan maka timbul motif lapar.

2. Motivasi ditandai oleh timbulnya perasaan (affective arousal). Mula- mula berupa ketegangan psikologis yang berubah menjadi emosi, misalnya dalam suasana diskusi untuk mengemukakan pendapat pribadi.

3. Motivasi ditandai oleh reaksireaksi mencapai tujuan.

Reaksi atau respon yang dikeluarkan merupakan upaya mengurangi ketegangan dalam mencapai tujuan tertentu, misalnya dalam mendapat nilai yang 
baik seorang pelajar banyak membaca buku dan bertanya dalam pelajaran sekolah. Duncan, seorang ahli administrasi mengemukakan bahwa di dalam konsep manajemen, "motivasi berarti setiap usaha yang disadari untuk mempengaruhi perilaku seseorang agar meningkatkan kemampuannya secara maksimal untukmencapai tujuan organisasi". Senada dengan pernyataan motivasi tersebut, masih dalam buku Purwanto menurut John P. Campbell dan kawan-kawan menambahkan rincian dalam definisi tersebut dengan mengemukakan bahwa “ motivasi mencakup didalamnya arah dan tujuan tingkah laku, kekuatan respon, dan kegigihan tingkah laku". Di samping itu, istilah itu pun mencakup sejumlah konsep seperti dorongan, kebutuhan, rangsangan, ganjaran penguatan, ketetapan tujuan, harapan, dan sebagainya.

Motivasi memiliki dua komponen, yakni komponen dalam (inner component) dan kemampuan luar (outer component). Komponen dalam ialah perubahan dalam diri seseorang, keadaan merasa tidak puas dan ketegangan psikologis, komponen luar adalah keinginan ndan tujuan yang mengarahkan perbuatan seseorang. Komponen dalam adalah kebutuhan-kebutuhan yang ingin dipuaskan, sedangkan komponen luar adalah tujuan yang hendak dicapai.

Menurut sifatnya motivasi dibagi menjadi dua yaitu motivasi intrinsic dan motivasi ekstrinsik. Motivasi intrinsik adalah dorongan yang dikarenakan orang tersebut senang melakukannya. Sedangkan motivasi ekstrinsik adalah dorongan terhadap perilaku seseorang yang ada diluar perbuatan yang dilakukannya. Perlu diketahui bahwa siswa yang memiliki motivasi intrinsik akan memiliki tujuan menjadi orang yang terdidik, yang berpengetahuan, yang ahli dalam bidang studi tertentu. Satu-satunya jalan untuk menuju ketujuan yang ingin dicapai ialah belajar, tanpa belajar tidak akan menjadi ahli. Dorongan yang menggerakkan itu bersumber pada suatu kebutuhan yang berisikan keharusan untuk menjadi orang yang terdidik dan berpengetahuan, sehingga dapat dikatakan motivasi itu muncul dari kesadaran diri sendiri dengan tujuan secara esensial, bukan sekedar simbol dan seremonial. Demikian pula pendapat yang dikemukakan oleh Wlodkowski (1985) bahwa, "motivasi yang dimiliki dan dibawa individu ke dalam lingkungan belajar berpengaruh kuat terhadap apa dan bagaimana mereka belajar "Motivasi sangat berfungsi guna menumbuhkan kemauan dan semangat belajar siswa. Menurut Sardiman fungsi dari motivasi adalah :

1. Motif itu mendorong manusia untuk berbuat. Jadi sebagai penggerak atau motor yang melepaskan energi. Motivasi dalam hal ini merupakan motor penggerak dari setiap kegiatan yang akan dikerjakan.

2. Motif itu menentukan arah perbuatan. Yakni ke arah tujuan yang hendak dicapai.

3. Motif itu menyeleksi perbuatan kita. Artinya menentukan perbuatan- perbuatan mana yang harus dilakukan, yang serasi, guna mencapai

\section{Konsep Hasil Belajar}

Belajar bukan hanya mengingat, akan tetapi lebih luas daripada itu, yakni mengalami. Hasil belajar bukan suatu penguasaan hasil latihan, melainkan perubahan kelakuan. Anak-anak disuruh mempelajari berbagai macam mata pelajaran yang memberinya berbagai pengetahuan yang menjadi miliknya. Pendapat lain yang lebih terkenal tentang belajar sebagai perubahan kelakuan atau "change of behavior" di berikan oleh Ernest R. Hilgard, sebagai berikut:" "Learning is the process, by which an activity originates or changed 
through htraining procedures (Whether in the environment) as distinguishe from changes by factors not attributable to training (yang artinya belajar adalah sebuah proses yang berasal dari kegiatan atau perubahan tingkah laku latihan)".

Menurut Gagne belajar terdiri dari tiga tahap yang meliputi Sembilan fase. Tahapan itu sebagai berikut: (a) persiapan untuk belajar, (b) perolehan dan untuk perbuatan (performansi), dan (c) alih belajar. Pada tahap persiapan dilakukan tindakan mengarahkan perhatian, pengharapan, dan mendapatkan kembali informasi. Pada tahap pemerolehan dan performansi digunakan untuk persepsi selektif, sendi semantic, pembangkitkan kembali dan respon, serta penguatan. Tahap alih belajar meliputi pengisyaratan untuk membangkitkan pemberlakuan secara umum. Adanya tahap dan fase belajar tersebut mempermudah guru untuk melakukan pembelajaran.

James O. Whittaker, misalnya merumuskan "belajar sebagai proses dimana tingkah laku ditimbulkan atau diubah melalui latihan ataupengalaman". Dimana pendapat tersebut di dukung pula dengan penguatan Slameto tentang definisinya bahwa "belajar adalah proses usaha yang dilakukan individu untuk memperoleh suatu perubahan tingkah laku yang baru secara keseluruhan, sebagai hasil pengalaman individu itu sendiri dalam interaksi dengan lingkungannya". Dalam pengertian ini dapat dipahami belajar merupakan interaksi siswa dengan lingkungannya yang secara khusus adalah lingkungan yang menjadi tempat untuk siswa belajar sehingga terjadi proses mengamati dan mengambil manfaat yang baik untuk dapat diserap dan dijadikan tambahan pengetahuan untuk dirinya.

Menurut Cronbach tentang belajar, "Learning is shown by a change in behavior as result of experience"(belajar itu tampak oleh perubahan tingkah laku sebagai akibat dari pengalaman)

Belajar juga didefinisikan oleh Harold Speech yakni, "Learning is to observe, to read, to imitate, to try something themselves, to listen, to follow direction"(perubahan tingkah laku dengan serangkaian kegiatan misalnya dengan membaca, mengamati, mendengarkan, meniru dan sebagainya).

\section{PEMBAHASAN}

\section{Pengertian Sistem Pendukung Keputusan}

Menurut Marimin dan Nurul (2010) Sistem adalah suatu kesatuan usaha yang terdiri dari bagian-bagian yang berkaitan satu sama lain yang berusaha mencapai suatu tujuan dalam suatu lingkungan kompleks. Pengertian tersebut mencerminkan adanya beberapa bagian dan hubungan antara bagian, ini menunjukkan kompleksitas dari sistem yang meliputi kerja sama antara bagian yang independent satu sama lain. Selain itu dapat dilihat bahwa sistem berusaha mencapai tujuan. Pencapaian tujuan ini menyebabkan timbulnya dinamika, perubahan-perubahan yang terus-menerus perlu dikembangkan dan dikendalikan.

Menurut Efraim (2005) Sistem pendukung keputusan sebagai sekumpulan prosedur berbasis model untuk data pemrosesan dan penilaian guna membantu para manajer mengambil keputusan untuk sukses, sistem tersebut haruslah sederhana, cepat, mudah dikontrol, adaptif lengkap dengan isu-isu penting, dan mudah berkomunikasi.

Dari definisi tersebut, dapat diindikasikan empat karakteristik utama dari sistem pendukung keputusan, yaitu: 
1. Sistem pendukung keputusan menggabungkan data dan model menjadi satu bagian.

2. Sistem pendukung keputusan dirancang untuk membantu para manajer (pengambil keputusan) dalam proses pengambil keputusan dari masalah yang bersifat semi struktural (tidak terstruktur).

3. Sistem pendukung keputusan lebih cenderung dipandang sebagai penunjang penilaian manajer dan sama sekali bukan untuk menggantikannya.

4. Teknik sistem pengambil keputusan dikembangkan untuk meningkatkan efektivitas dari pengambil keputusan.

Aplikasi dari sistem pengambil keputusan baru dapat dikatakan berhasil atau bermanfaat, jika terdapat kondisi sebagai berikut:

1. Eksistensi dari basis data yang sangat besar, sehingga sulit mendayagunakannya.

2. Kepentingan adanya transformasi dan komputasi pada proses pencapaian keputusan.

3. Adanya keterbatasan waktu, baik dalam penentuan hasil maupun dalam prosesnya.

4. Kepentingan akan penilaian atas pertimbangan akal sehat untuk menentukan dan mengetahui pokok permasalahan, serta pengembangan alternatif dan penilain solusi.

\section{Pengertian Logika Fuzzy}

Menurut Sri Kusumadewi (2006) sebelum munculnya teori logika fuzzy (fuzzy logic) dikenal sebuah logika tegas (crisp logic) yang memiliki nilai benar dan salah secara tegas. Sebaliknya logika fuzzy adalah Suatu logika yang memiliki nilai kekaburan atau kesamaran (fuzzyness) antara benar dan salah. Dalam teori logika fuzzy suatu nilai bisa bernilai benar dan salah secara bersamaan. Namun berapa besar kebenaran dan kesalahan suatu nilai tergantung pada bobot keanggotaan yang dimilikinya. Orang yang belum mengenal logika fuzzy pasti akan mengira bahwa logika fuzzy adalah suatu yang amat rumit dan tidak menyenangkan. Namun, sekali orang mengenalnya, ia pasti akan sangat tertarik dan akan menjadi pendatang baru untuk ikut serta mempelajari logika fuzzy. Logika fuzzy dikatakan sebagai logika baru yang lama, sebab ilmu tentang logika fuzzy modern dan metodis baru ditemukan beberapa tahun yang lalu, padahal sebenarnya konsep tentang logika fuzzy itu sendiri sudah ada pada diri kita sejak lama. Logika fuzzy adalah suatu cara yang tepat untuk memetakan suatu ruang input ke dalam suatu ruang output.

\section{Metode Mamdani}

Metode mamdani sering juga dikenal dengan nama Metode Max-Min. Metode ini diperkenalkan oleh Ebrahim Mamdani pada tahun (1975:34). Menurut Kusumadewi (2006:3) untuk mendapatkan output, diperlukan 4 tahapan:

1. Pembentukan himpunan fuzzy. Menentukan variabel fuzzy dan himpunan fuzzinya. Kemudian tentukan derajat keanggotaan antara data masukan fuzzy dengan himpunan fuzzy yang telah didefenisikan untuk setiap variabel masukan sistem dari setiap aturan fuzzy. 
2. Aplikasi fungsi implikasi pada metode mamdani. Fungsi implikasi yang digunakan adalah min. Hasil implikasi fuzzy dari setiap aturan ini kemudian digabungkan untuk menghasilkan keluaran infrensi fuzzy.

3. Komposisi Aturan (rule). Tidak seperti penalaran monoton, apabila sistem terdiri dari beberapa aturan, maka infrensi diperoleh dari kumpulan dan korelasi antar aturan. Ada 3 metode yang digunakan dalam melakukan inferensi sistem fuzzy, yaitu: max, additive dan Jumlah babilistik AND.

4. Penegasan (defuzzy). Defuzzifikasi adalah suatu himpunan fuzzy yang diperoleh dari komposisi aturan-aturan fuzzy, sedangkan output yang dihasilkan merupakan suatu bilangan pada domain himpunan fuzzy.

Menurut Eng. Agus Naba (2009:2), Motivasi utama teori fuzzy logic adalah memetakan sebuah ruang input ke dalam ruang output dengan menggunakan IFTHEN Rule. Pemetaan dilakukan dalam suatu FIS, urutan rule bisa sembarang. FIS mengevaluasi semua rule secara simultan untuk menghasilkan kesimpulan. Oleh karenanya, semua rule harus didefinisikan lebih dahulu sebelum kita membangun sebuah FIS yang akan digunakan untuk menginterpretasikan semua rule tersebut. Mekanisme dalam FIS bisa dirangkum yaitu: FIS adalah sebuah metode yang menginterpretasikan harga-harga dalam vektor input, menarik kesimpulan berdasarkan sekumpulan IF-THEN rule yang diberikan, dan kemudian menghasilkan vektor output.

Dalam penyusunan penerapan logika fuzzy mamdani untuk menentukan tingkat kecemasan mahasiswa dalam menghadapi skripsi terdapat beberapa langkah yang harus dilakukan untuk mendapatkan data yang valid dalam penyusunannya.

Setelah dilakukan perhitungan dan percobaan, maka didapatlah hasil penentuan kondisi kecemasan yang dihadapi dengan menerapkan metode fuzzy mamdani dengan matlab.

\section{Menentukan Himpunan Fuzzy}

1. Variabel intelektual (IQ) Variabel input intelektual (IQ)meliputi Kemamapuan Memecahkan Masalah, Intelegensi Verbal dan Intelegensi Praktis.

2. Variabel Motivasi Belajar

Variabel input Motivasi Belajar meliputi Ketekunan dalam belajar ,Ulet dalam menghadapi kesulitan ,Minat dan ketajaman perhatian dalam belajar,

Berprestasi dalam belajar, Mandiri dalam belajar. tabel 1 .

Dari kondisi gejala-gejala di atas dapat dibentuk himpunan fuzzy seperti pada 
Research and Development Journal Of Education

Vol. 2 No. 2 April 2016

ISSN 2406-9744

Tabel 1. Pembentuk himpunan fuzzy

\begin{tabular}{|c|c|c|c|c|c|}
\hline \multirow[t]{2}{*}{ Fungsi } & \multirow[t]{2}{*}{ Nama Variabel } & \multirow[t]{2}{*}{ Range } & \multicolumn{3}{|c|}{$\begin{array}{c}\text { Nama Himpunan Fuzzy } \\
\text { (Domain) }\end{array}$} \\
\hline & & & Buruk & Cukup & Baik \\
\hline \multirow{4}{*}{ Input } & intelektual (IQ) & $(0-10)$ & $(0-5)$ & $(4-8)$ & $(7-10)$ \\
\hline & Kemamapuan Memecahkan Masalah & $(0-10)$ & $(0-5)$ & $(4-8)$ & $(7-10)$ \\
\hline & Intelegensi Verbal & $(0-10)$ & $(0-5)$ & $(4-8)$ & $(7-10)$ \\
\hline & Intelegensi Praktis & $(0-10)$ & $(0-5)$ & $(4-8)$ & $(7-10)$ \\
\hline & Motivasi Belajar & $(0-10)$ & $(0-5)$ & $(4-8)$ & $(7-10)$ \\
\hline \multirow{5}{*}{ Input } & Ketekunan dalam belajar & $(0-10)$ & $(0-5)$ & $(4-8)$ & $(7-10)$ \\
\hline & Ulet dalam menghadapi kesulitan & $(0-10)$ & $(0-5)$ & $(4-8)$ & $(7-10)$ \\
\hline & $\begin{array}{l}\text { Minat dan ketajaman perhatian dalam } \\
\text { belajar }\end{array}$ & $(0-10)$ & $(0-5)$ & $(4-8)$ & $(7-10)$ \\
\hline & Berprestasi dalam belajar & $(0-10)$ & $(0-5)$ & $(4-8)$ & $(7-10)$ \\
\hline & Mandiri dalam belajar & $(0-10)$ & $(0-5)$ & $(4-8)$ & $(7-10)$ \\
\hline Output & Hasil Belajar & $(0-10)$ & $(0-5)$ & $(4-8)$ & $(7-10)$ \\
\hline
\end{tabular}

\section{Fuzzifikasi}

Fungsi derajat keanggotaan yang digunakan adalah fungsi linier turun, fungsi segitiga dan fungsi linier naik.

Fungsi linier naik $\quad \mu[\mathrm{x}]=\left\{\begin{array}{lr}0 ; & x \leq a \\ \frac{x-a}{b-a} ; & a \leq x \leq b \\ 1 . & v>h\end{array}\right.$

Fungsi linier turun $\quad \mu[\mathrm{x}]= \begin{cases}\frac{b-x}{b-a} ; & a \leq x \leq b\end{cases}$

Fungsi segitiga

$$
\mu[\mathrm{x}]=\left\{\begin{array}{lr}
0 ; & x \leq a \text { atau } x \geq c \\
\frac{(x-a)}{(b-a)} ; & a \leq x \leq b \\
\frac{(b-x)}{(c-b)} ; & b \leq x \leq c
\end{array}\right.
$$

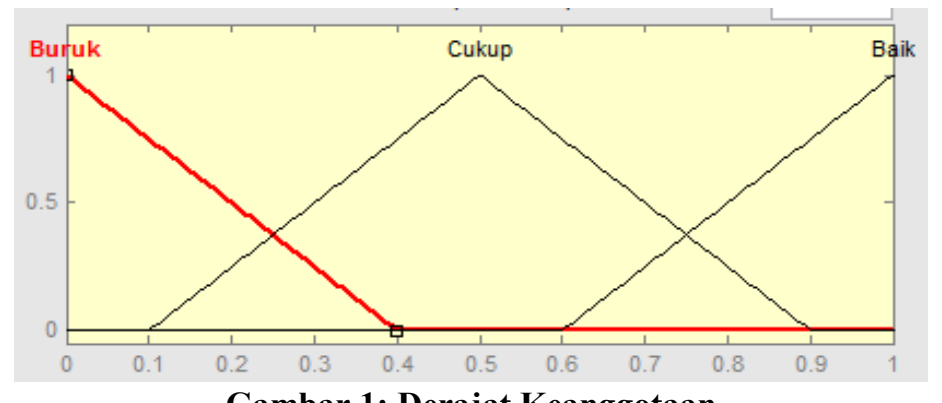

Gambar 1: Derajat Keanggotaan

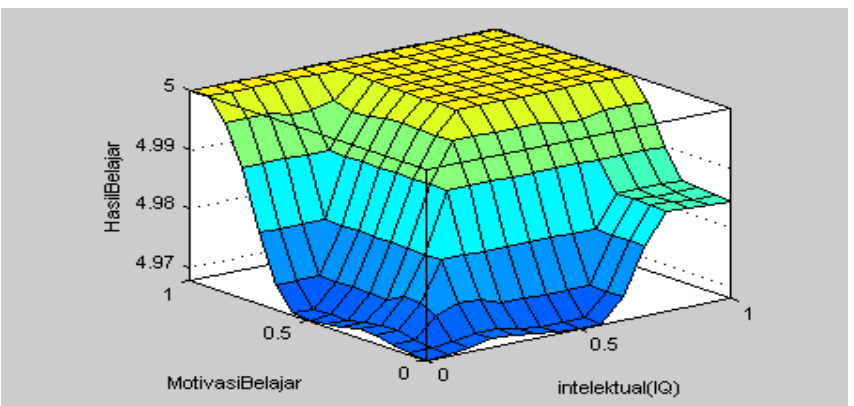

Gambar 2: Surface Viewer 


\section{Pembentukan basis pengetahuan Fuzzy}

Tahap berikutnya membentuk basis pengetahuan yang berisi aturan-aturan (rule) dalam bentuk IF... THEN yang disesuaikan dengan penelitian yang telah dilakukan.

\section{Aplikasi fungsi implikasi}

Fungsi ini digunakan untuk mendapatkan nilai $\alpha$-predikat hasil implikasi dengan cara memilih output himpunan fuzzy sesuai dengan derajat keanggotaan yang terkecil.

\section{Komposisi antar-rule}

Solusi himpunan fuzzy diperoleh dengan cara mengambil nilai maksimum aturan, kemudian menggunakannya untuk memodifikasi daerah fuzzy, dan mengaplikasikannya ke output dengan menggunakan operator AND.

\section{Defuzzyfikasi}

Input dari proses defuzzifikasi adalah suatu himpunan fuzzy yang diperoleh dari komposisi aturan-aturan fuzzy, sedangkan output yang dihasilkan merupakan suatu bilangan pada domain himpunan fuzzy tersebut. Sehingga jika diberikan suatu himpunan fuzzy dalam range tertentu, maka harus diambil suatu nilai crsip tertentu sebagai output. Dan metode yang digunakan adalah metode Centroid, dimana solusi crisp diperoleh dengan cara mengambil titik pusat $\left(z^{*}\right)$ daerah fuzzy. Secara umum dirumuskan: $z^{*}=\int \mu(z) z d z \int \mu(z) d z$.

\section{SIMPULAN}

Jadi simpulan dari penelitian ini adalah:

1. Penentuan pengaruh kemampuan hasil belajar mata kuliah akutansi berdasarkaninteletual (IQ) dan motivasi belajar dengan metode fuzzy tingkat dapat diketahui dengan cepat.

2. Penentuan pengaruh kemampuan hasil belajar dapat menggunakan Matlab R2009b, sehingga bisa dikembangkan dengan menggunakan alat bantu lain, agar nantinya bisa didapatkan interface yang lebih interaktif.

3. Penerapan logika fuzzy mamdani disini hanya sebatas penentuan pengaruh kemampuan hasil belajar siswa tehadap mata kuliah akutansi.

\section{DAFTAR PUSTAKA}

B.Uno, Hamzah. 2011. Teori Motivasi. Jakarta : Bumi Aksara.

Djamarah, Syaiful Bahri . 2002. Psikologi Belajar. Jakarta : Rineka Cipta.

Eng. Agus Naba. 2009. Belajar Cepat Fuzzy Logic menggunakan Matlab. Yogyakarta: Andi Offset.

Kusumadewi, Sri \& Hartati,Sri \& Harjoko, Agus \& Retantyo,Wardoyo. 2006. Fuzzy Multi-Attribute Decision Making (Fuzzy MADM). Yogjakarta: Graha Ilmu. 
Research and Development Journal Of Education

Vol. 2 No. 2 April 2016

ISSN 2406-9744

Marimin, Nurul, 2010, Aplikasi Teknik Pengambilan Keputusan dalam Manajemen Rantai Pasok, IPB Press, Bogor.

Sardiman A.M.. 2008. Interaksi dan Motivasi Belajar Mengajar. Jakarta : Raja Grafindo.

Slameto. 2003Belajar dan Faktor- Faktor Yang Mempengaruhi. Jakarta : Bumi Aksara.

Syah, Muhibbin. ,2005.Psikologi Pendidikan. Bandung : Remaja Rosdakarya. 